\title{
Author Correction: Orbital- and millennial-scale Antarctic Circumpolar Current variability in Drake Passage over the past 140,000 years
}

Shuzhuang Wu D, Lester Lembke-Jene (D), Frank Lamy (1D, Helge W. Arz DiD, Norbert Nowaczyk, Wenshen Xiao, Xu Zhang $\mathbb{D}^{1}$, H. Christian Hass, Jürgen Titschack (1), Xufeng Zheng, Jiabo Liu, Levin Dumm, Bernhard Diekmann, Dirk Nürnberg, Ralf Tiedemann \& Gerhard Kuhn (1)

Correction to: Nature Communications https://doi.org/10.1038/s41467-021-24264-9, published online 24 June 2021.

The original version of this Article contained an error in Fig. 1, in which the unit for the variable "Current speed" was given as "m/s", but should be "cm/s". This has been corrected in both the PDF and HTML versions of the Article.

Published online: 10 January 2022

(c) (i) Open Access This article is licensed under a Creative Commons Attribution 4.0 International License, which permits use, sharing, adaptation, distribution and reproduction in any medium or format, as long as you give appropriate credit to the original author(s) and the source, provide a link to the Creative Commons license, and indicate if changes were made. The images or other third party material in this article are included in the article's Creative Commons license, unless indicated otherwise in a credit line to the material. If material is not included in the article's Creative Commons license and your intended use is not permitted by statutory regulation or exceeds the permitted use, you will need to obtain permission directly from the copyright holder. To view a copy of this license, visit http://creativecommons.org/licenses/by/4.0/.

(c) The Author(s) 2022 